\title{
How race travels: relating local and global ontologies of race
}

\author{
David Ludwig1 1
}

Published online: 6 August 2018

(C) The Author(s) 2018

\begin{abstract}
This article develops a framework for addressing racial ontologies in transnational perspective. In contrast to simple contextualist accounts, it is argued that a globally engaged metaphysics of race needs to address transnational continuities of racial ontologies. In contrast to unificationist accounts that aim for one globally unified ontology, it is argued that questions about the nature and reality of race do not always have the same answers across national contexts. In order address racial ontologies in global perspective, the article develops a framework that accounts for both continuities and discontinuities by looking beyond the referents of narrowly defined core concepts. By shifting the focus from narrow concepts to richer conceptions of race, racial ontologies become comparable through globally related but nonetheless distinct mappings between conceptions and property relations. The article concludes by showing how this framework can generate novel insights in case studies from Asia, Europe, and Latin America.
\end{abstract}

Keywords Metaphysics of race - Philosophy of race - Social ontology - Conceptual change $\cdot$ Conceptions $\cdot$ Comparative philosophy

\section{Introduction}

W. E. B. Du Bois' 1952 lecture "The Negro and the Warsaw Ghetto" develops an autobiographical perspective on the challenges of thinking about race across borders. Reflecting on his time at the University of Berlin in 1893-1894, Du Bois remarks that "race problems at the time were to me purely problems of color, and

David Ludwig

david.ludwig@wur.nl

1 Knowledge, Technology, and Innovation (KTI) Group, Wageningen University, Hollandseweg 1, $6706 \mathrm{KN}$ Wageningen, The Netherlands 
principally slavery in the United States and near slavery in Africa" $(1971,250)$. And indeed, this focus is clearly reflected in Du Bois' most influential works including his famous claim that "the problem of the twentieth century is the problem of the color-line" (2007, xiv). In his address to the Jewish Life Tribute to the Warsaw Ghetto Fighters, however, Du Bois reflects on his encounter with a broader "race problem [that] cut across lines of color and physique [...] and was a matter of cultural patterns, perverted teaching and human hate and prejudice, which reached all sorts of people" $(1971,253)$. Rather than addressing race exclusively in terms of the color line, Du Bois therefore embraces a global perspective that moves engagement with race beyond "social provincialism into a broader conception" (1970, 253).

Du Bois' case for a transnationally informed "broader conception" and against "social provincialism" constitutes an important challenge for current debates about the metaphysics of race that tend to be limited to the United States with little concern for racial concepts and processes on a global scale (Atkin 2017). In this sense, Spencer $(2014 a, 41)$ is largely correct when he defines the "philosophical race debate" as an American affair that is concerned with "the nature and reality of race as understood by current ordinary folk in the U.S." (emphasis added).

The aim of this article is to develop a framework for expanding the scope of metaphysics of race and engagement with racial ontologies on a global scale. Section 2 introduces contextualism as a common background assumption in the current metaphysics of race. Assuming that different contexts require different ontologies of race, one may conclude that the project of a globally oriented metaphysics of race is either uninformative or incoherent. While the transnational heterogeneity of processes of racialization indeed requires some kind of contextualism, it is argued that a simple contextualism misses how many of these processes extend across (cultural, linguistic, geographic, social, and political) borders. Section 3 argues that the alternative to contextualism is not a unificationism that downplays transnational variation in the pursuit of one globally unified ontology of race. The insights and shortcomings of both contextualism and unificationism provide the foundation for an alternative and relational framework that addresses ontologies of race in terms of globally related but nonetheless distinct mappings between conceptions and property relations, ${ }^{1}$ While Sect. 4 outlines a general strategy for approaching racial ontologies as globally related but not identical, Sect. 5 illustrates the benefits of this strategy through three case studies from Asia, Europe, and Latin America.

\footnotetext{
1 Addressing ontologies of race through conceptions and property relations is not supposed to presuppose racial realism. For example, the framework builds on an analysis of race conceptions that often involve false racialist assumptions and therefore do not fully map onto existing property relations. Furthermore, I use the example of post-Holocaust Germany to argue that at least some racial ontologies emphasize these racialist dimensions so strongly that realist interpretations become implausible.
} 


\section{Contextualism and its limitations}

While metaphysics of race is concerned with the nature and reality of race, much of the current literature is (implicitly or explicitly) restricted to the nature and reality of race in the United States. This restriction is not unique to a specific metaphysical position but widely shared by otherwise incompatible accounts from anti-realism to biological realism.

For example, anti-realists about race often employ "mismatch arguments" to show that talk about real biological or social groups is not talk "about race, at least not in the relevant, ordinary, folk sense of the term" (Glasgow 2010, 55). Glasgow defends this claim by providing detailed evidence of "relatively non-negotiable conceptual commitments [...] that prevent us from understanding race" as real biological or social groups. My aim here is not to evaluate Glasgow's evidence but only to point out that he does not (and does not claim to) provide evidence for these conceptual commitments in countries such as China, Italy, Libya, Myanmar, Peru, Russia, or Zimbabwe. Instead, Glasgow's appeal to "our language use and and practices" is best interpreted as limiting his claims to a much more restricted context of the United States (and potentially some additional Anglophone countries).

Appeals to American language use are not limited to anti-realism but also an important component of arguments for competing positions such as biological realism about race. For example, Spencer's two-step argument for biological realism combines empirical claims about human population structure with conceptual claims about the "US meaning of 'race" (2014b, 1027). First, Spencer argues that contemporary population genetics identifies continental clusters that form what he calls the "Blumenbach partition". Second, he argues that the Blumenbach partition is also identified by United States Census racial categories and should be considered the referent of race. Spencer could therefore be hardly more explicit about the limitation of his biological realism to what he calls the "national meaning of 'race' in the United States" (2014b, 1026).

\subsection{Contextualizing ontologies}

One may be tempted to treat the US-centrism of current metaphysical debates as a reductio by pointing out that the nature and reality of race is not exclusively an American affair. However, it would be a mistake to assume that philosophers of race are not aware of contextual variation beyond the United States. Instead, metaphysical restrictions to the United States tend to be justified through the meta-metaphysical assumption that "race does not travel" (Root 2000, 631) and that there is no transnationally valid ontology of race. According to such a contextualism, accounts of the nature and reality of race have to be restricted to specific national contexts. American philosophers of race are therefore perfectly justified to limit their arguments to the US ontology of race just as Indonesian or Sudanese 
philosophers could limit their arguments to Indonesian or Sudanese ontologies of race. $^{2}$

One can make contextualist background assumptions more explicit by following Glasgow's (2011) suggestion of adding indices to concepts of race. Glasgow proposes this strategy to clarify that he is concerned with the folk concept of race rather than a more specialized (e.g. biomedical) concept of race. Just as this can be clarified by talking about race $_{\text {folk }}$ and race $_{\text {biomedical }}$, one may also clarify temporal and geographical contextuality by adding further indices. In this sense, much of the ontological debate should be understood as being concerned with the referent of race $_{\text {folk-contemporary-Us. }}$. Furthermore, metaphysicians of race do not have to worry about their analyses being inadequate for race $_{\text {folk-1894-France, }}$ race $_{\text {biomedical-contemporary-Israel, }}$ or even race $_{\text {folk-2003-Darfur }}$ because they never claimed to say anything about these contexts.

\subsection{Problems with simple contextualism}

While the global variation of racialized practices makes some form of contextualism necessary, contextualism alone is not sufficient for addressing racial ontologies on a global scale. Let us define simple contextualism as a position that reduces the metaphysics of race to debates about contextualized entities such as

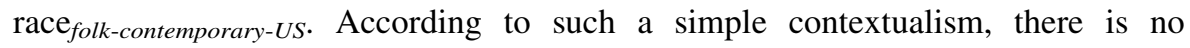
interesting debate about racial ontology beyond specific contexts because race does "not travel" between them.

This simple contextualist compartmentalization is inadequate because it fails to address the global nature of many racialization processes. For example, Root (2000, 631 ) is right to point out that a black man in the United States may not be counted as black in Brazil (see Muniz and Bastos 2017) but this does not mean that there are no meaningful continuities between these countries. Most obviously, racialization processes in Brazil and the United States are both the product of European settler colonialism and the transatlantic slave trade. Understanding these processes requires engagement with their transnational nature. Of course, there are also many meaningful differences in how racialization works in Brazil and the United States from affirmative action (Oliven 2007) to medical sciences (Chor and Lima 2005). However, a discussion that only considers contextual variation without acknowledging the existence of global racialization processes will provide an incomplete metaphysical picture and at best a partial answer to the ontological question of what there is. At the very least, contextualized debates about localized processes that "do not travel" have to be supplemented with a globally informed debate that

\footnotetext{
2 There is a political problem with this line of argument that I am not going to explore further but that is illustrated by the lack of extensive debates about Indonesian or Sudanese (or really any non-Anglophone) ontologies of race in major philosophy journals: A simple contextualist division of labor generates epistemic injustices that mirror current hierarchies between global centres and peripheries of academic philosophy. In this sense, the emergence of analytic metaphysics of race may have contributed to a better understanding of racialization in the United States but has certainly not made substantial contributions to understanding racialization in global contexts such as Sudan (e.g. in the genocide in Darfur) to Indonesia (e.g. in the independence of Timor-Leste).
} 
investigates how racialization processes "do travel" across cultural, linguistic, social, and political borders.

While analytic metaphysics of race has largely neglected issues of transnational continuity, the global character of racialization has been at the centre of other engagements with race in anti-colonial, black nationalist, and "Third World" Marxist traditions. One widely shared assumption in these traditions is that racialization is at its core a global process because it is grounded in an equally global system of colonization and white supremacy. Cruse's 1962 essay "Revolutionary Nationalism and the Afro-American" illustrates this line of argument by insisting that race in the United States is still colonial in nature: "From the beginning, the American Negro has existed as a colonial being. His enslavement coincided with the colonial expansion of European powers and was nothing more or less than a condition of domestic colonialism. Instead of the United States establishing a colonial empire in Africa, it brought the colonial system home and installed it in the Southern states" $(2009,76)$. This idea of a "black colony" did not only allow Cruse to conceive race in the United States as a national expression of a global phenomenon but also became widely adopted by black nationalist movements of the 1960s including the Black Panther Party (e.g. 10 Point Program, $\S 10$ ) and the Revolutionary Action Movement (e.g. 12-Point Program, §9), which used the idea of racialization as colonization as the foundation of radical anticolonial and internationalist politics.

While these anti-colonial and internationalist framings of race from the 1960s have lost much influence in racial discourse, critical race theory often continues to address race as a global phenomenon that is grounded in an equally global system of white supremacy. For example, Winant's The World is a Ghetto (2001) provides a helpful reconsideration of a "world racial system" at the beginning of the twentyfirst century. Winant starts with an analysis of what he describes as "the break" in the "old world racial system" after World War II through global movements that challenged colonialism and explicit systems of white supremacy from apartheid in South Africa to Jim Crow in the United States. Winant stresses that these movements have been successful in forcing a "worldwide rupture of the racial status quo" $(2001,1)$ and that the "world underwent a profound shift in the global logic of race, a crisis of world racial formation" (2004, 15).

However, Winant also insists that this rupture has led to a transformation rather than disappearance of the "world racial system". Following Gramsci's ([1926] 2014) distinction between direct domination and cultural hegemony, Winant characterizes the world racial system as shifting from dominant to hegemonic "white supremacy [that] has proven itself capable of [...] repackaging itself as 'colorblind,' nonracialist, and 'meritocratic' (2004, xiii)." While invisibility of oppression is a core feature of any system of hegemony that replaces the direct violence of systems of domination, the hegemonic character of the current racial system still almost universally enforces white supremacy: "Pick any relevant sociological indicator-life expectancy, infant mortality, literacy, access to health care, income levels - and apply it in virtually any setting, global, regional, or local, and the results will be the same: the worldwide correlation of wealth and well-being with white skin and European descent" $(2001,35)$. 
While Winant could hardly be more explicit in claiming ontological significance of his analysis for understanding race as a "socially constructed and politically contested" $(2004,39)$ category, the global character of white supremacy is rarely at the centre of debates about the nature and reality of race in analytic metaphysics. An important exception is Mills' version of social constructionism that addresses race as a reality that is created through "white supremacy as a sociopolitical system" (2003). Mills not only emphasizes the global character of white supremacy but also its status as "a theoretical object in its own right-a global social system comparable in current significance [...] to Marx's class society and feminist thinkers' patriarchy" (2003, 178). Given Mills' framing, a simple contextualism that ignores the transnational character of white supremacy would be as inadequate for understanding the nature of race as a metaphysics of class that ignores the global character of capitalism.

While there remains considerable room for disagreement about the exact role of global issues in racial ontologies, the internationalist tradition in critical race theory indicates that a simple contextualism, which is limited to relativized ontologies such

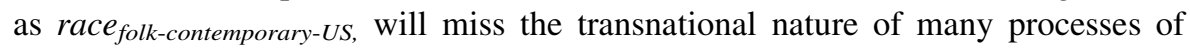
racialization. As a result, it provides at best an incomplete framework for a globally engaged metaphysics of race and runs the risk of obscuring the global nature of racialization.

\section{Unificationism and its limitations}

One may react to the limitations of contextualism by proposing a radically different strategy that aims for one globally unified ontology and provides transnational answers to questions about the nature and reality of race. This section presents two different ways of developing such a unificationism. First, one may propose unificationist ontologies on the basis of global "white supremacy" in the sense of the last section. Second, one may follow Hardimon (2017) who has argued for the global relevance of a minimalist race concept in terms of visible features that mark common and distinctive geographical ancestry. This section argues that both strategies invert the problems from the last section. While a simple contextualism fails to account for important transnational continuities, a simple unificationism fails to account for transnational variation of the nature and reality of race.

\subsection{Unification through global white supremacy}

In developing his account of white supremacy as a sociopolitical system, Mills (2003, 180) emphasizes that "insofar as the modern world has been foundationally shaped by European colonialism, white supremacy could be seen as transnational, global, the historic domination of white Europe over non-white non-Europe". Acknowledgment of a transnational colonial system of white supremacy, however, does not imply endorsement of a unificationist ontology that globally answers questions about the nature of race in terms of positioning in this system. There are at least two reasons for this. First, white supremacy may constitute a transnational 
system of racialization without constituting the only system of racialization. Second, a system of white supremacy may exist across contexts but still not constitute the referent of concepts of race across all of them.

To illustrate the first concern, consider the intra-European history of racialization and especially antisemitism. Indeed, there remains considerable disagreement about the question at what historical stage Jews became a racialized group with some authors including medieval forms of antisemitism while others locate racialization more firmly in modernity (see Bessone 2013; Doron 2016; Heng 2011). Even if the racialization of Jews does not the predate colonial projects of white supremacy, however, it would still be historically inaccurate to consider the process reducible to white supremacy of modern European colonialism. For example, Germany's colonial aspirations in the nineteenth century certainly interacted with German antisemitism but it would be inaccurate to think of the latter being reducible to the former (Geulen 2004; Hund 2017). Understanding racial ontologies in nineteenth century Germany only in terms of a colonial system of white supremacy would misunderstand a system that racialized Jews with distinct methods (e.g. targeting an "invisible enemy" of assimilated Jews without phenotypic characteristics such as visible whiteness) and goals (e.g. establishment of distinctly Germanic supremacy over Jewish and Slavic people). In other words: Race may often be grounded in colonial project of white supremacy but at least occasionally also in other systems of racialization.

The possibility of multiple systems of racialization can also be motivated with controversies about the boundaries of race on a global scale. While there remains considerable disagreement about the scope of racial phenomena in global perspective (see Sect. 5.3), much of the recent literature has been critical of diffusionist models that address global racialization as a simple export from a European centre to its non-European peripheries. Diffusionist models have not only been criticized as reflecting a "Eurocentric interpretation of a Eurocentric ideology" (Berg and Wendt 2011, 2) but also become contrasted with alternative "interactionist" models that postulate multiple interacting systems of racialization (Bonnett 2018). Dikötter's work on the emergence of racial discourses in modern China ([1998] 2015) has been groundbreaking in this regard as it reconstructs the formation of racialized practices in China as the result of an interaction between European ideologies and distinctly Chinese concerns from the justification of Manchu rule to post-revolutionary nation-building. A global unification of racial ontologies in terms of white supremacy runs the risk of ignoring how these interactions have led to genuinely novel systems of racialization. For example, consider the case of anti-black violence in China from attacks against African students in the 1980s (Cheng 2011) to more recent repression of the African community in Guangzhou (Federl 2014). Thinking of race exclusively in terms of white supremacy runs the risk of failing to recognize such cases as racial because of their embedding in a distinctly Chinese system of racialization.

In addition to this multiplicity of systems of racialization, the multiplicity of concepts of race provides a further reason for skepticism about global unification. Even if a system of white supremacy exists across contexts, it may not always be the referent of local race concepts. For example, consider divergent developments of 
racial discourses in Germany and the United States after World War II. Even it is true that race in the United States is best understood as referring to a social kind that is the product of white supremacy, the same may not be true in post-Holocaust Germany where race is so strongly associated with debunked racialist Nazi ideology that claims about the social character and reality of race appear self-contradictory.

To illustrate this conceptual divergence, consider a policy paper of the Deutsches Institut für Menschenrechte (German Institute for Human Rights) on article 3 of German basic law that states that "no person shall be favoured or disfavoured because of [...] race" (Deutscher Bundestag 1949). The policy paper appeals to the German consensus about the non-existence of races in arguing for the elimination of this passage: "There seems to be awareness of the problems of the concept 'race' in Germany as well as a will to not use the concept anymore. Now is the time for the last step: the concept of race should not be used anymore in legal texts" (Cremer 2010,6 , translation by author). Note that the paper does not deny the existence of white supremacy in Germany and is actually motivated by the goal of improving anti-racist practices. However, it insists that the German concept of race refers to racialist illusions rather than social realities.

Recent debates about Weisssein ("whiteness") in Germany provide further evidence that recognition of social realities of white supremacy does not presuppose an account of race in terms of these realities. For example, Amjahid's (2017) book Unter Weissen ("Among Whites") dissects German practices of white supremacy but explicitly avoids realist appeals to Rasse by pointing out the "historical burden" $(2017,49)$ of the concept. In this sense, the German concept of race may indeed be more adequately understood in analogy to other failed concepts such as witch. While alleged witches were forced in very real social positions, claims about the reality of races in Germany seem just as misleading as claims about the reality of witches. ${ }^{3}$ A comparison of racial discourses in United States and Germany therefore illustrates a second challenge for the unification of racial ontologies: even if a sociopolitical system such as white supremacy extends transnationally, it may not always constitute the referent of local race concepts.

\subsection{Unification through a minimalist concept of race}

While white supremacy forms the basis for one potential strategy of global unification, Hardimon $(2017,31)$ has recently proposed a very different unificationism and argued that "race is now a world concept par excellence. It is clear that there are different conceptions of race. But it is plausible to assume that these different conceptions of race are articulations of one and the same concept".

\footnotetext{
${ }^{3}$ Even if it is true that the current German concept of race refers to false ideas in continuity of Nazi racialism, one may still wonder whether Germans should introduce a notion of race that identifies social realities. Although there is hardly a debate about this normative question of conceptual engineering (see footnote 6) in Germany, it has been occasionally endorsed by German academics who are influenced by American race discourses (Arndt 2009; Barskanmaz 2011). Analogous issues of negative effects of European colorblindness through elimination of racial discourses have been raised in other countries including France (Balibar 1992; Bessone 2013; Simon 2008) and the Netherlands (Schaap 2014; Wekker 2016).
} 
According to Hardimon, this global concept of race can be specified in terms of a "logical core" of three minimal biological requirements of (a) patterns of visible features (b) common ancestry (c) distinctive geographical ancestry. ${ }^{4}$

Unfortunately, Hardimon simply suggests the global applicability of his "logical core" without providing empirical evidence. In addition to this lack of positive evidence, the problems from 3.1 extend to Hardimon's brand of unificationism. First, a multiplicity of systems of racialization plausibly leads to a multiplicity of race concepts. For example, consider Hardimon's element (a) and his insistence on the necessity of actual patterns of visible features $(2017,34)$. Even if we accept that visible phenotypic variation applies to racialized groups in the United States, it does not apply to Jews as the major racialized group in much of European history. This may be an acceptable consequence for race $_{\text {folk-contemporary-US }}$ but raises doubts about the three elements (a)-(c) as a basis for a globally extended "world concept" of race.

Second, transnational conceptual variation provides more direct evidence for the inadequacy of Hardimon's logical core in global perspective. For example, Hardimon contrasts his core in the sense of (a)-(c) with racialist concepts of race that assume biological essences or normatively important differences. He argues that the ordinary concept of race is not racialist because "there is no contradiction in saying that Caucasians are a race but have no biological essences or that SubSaharan Africans are a race even though there is no normatively important feature common and peculiar to them" $(2017,29)$. As the earlier discussion of racial discourses in post-Holocaust Germany illustrates, there are reasons to assume that saying these things is actually contradictory in Germany because the dominant concept of race in Germany is not Hardimon's minimalist concept. As Plümecke $(2014,12)$ summarizes racial discourses in Germany: "'Rasse' is the unword of the last 60 years, semantically entangled with the purity and destruction-oriented eugenic policy of the Nazis. Not even racist pamphlets [...] are allowed to contain this word" (translation by author).

Even more straightforward evidence for the inadequacy of Hardimon's "world concept" hypothesis can be found in German reception of American race discourses such as recent controversies about Reich's (2018) article "How Genetics Is Changing Our Understanding of 'Race' "in the New York Times. An editorial of leading German researchers in the Süddeutsche Zeitung swiftly reacted to German reception of this controversy with a warning that "one should not confuse the American term 'race' with the German word 'Rasse'" (Lipphardt 2018, translation by author). The authors doubt that "race' means what German refers to as 'Rasse", and point out that race-talk in the United States is far more normalized than in Germany: "Many people in the US are accustomed to using 'race' or 'ethnicity' to

\footnotetext{
${ }^{4}$ Note that Hardimon's unificationism can be seen as limited by his case for a concept of socialrace that identifies hierarchical social positions rather than the three minimal features (a)-(c). While Hardimon therefore acknowledges the need for several concepts of human diversity, he is also very explicit in arguing that "SOCIALRACE is not a race concept" and that "the logical core in a committal way counts as a race concept proper" (2014, 76, emphasis in original). With regard to the "race concept proper", Hardimon's proposal therefore suggests a unificationist perspective.
} 
express their self-positioning in a community" (Lipphardt 2018, translation by author). While this normalization makes Hardimon's assumption of a restricted logical core appealing in the American context, the continued dominance of racialist associations with "Rasse" makes the same analysis implausible in Germany.

To sum up, unificationist perspectives on global racial ontologies face at least two problems. First, there is the problem of multiple material systems of racialization. Even if white supremacy or Hardimon's three minimal conditions apply transnationally in many contexts, it is doubtful that they apply in all contexts to all racialized groups. For example, it is not obvious how either of these proposals would analyze the case of antisemitism in Europe. Second, there is the problem of multiple diverging racial discourses that have led to the development of different race concepts. Even if structures such as white supremacy or Hardimon's three conditions are stable across contexts, it may turn out that they do not constitute the referent of all local race concepts.

\section{A framework for relating racial ontologies}

While there are limitations to unificationist and contextualist accounts of racial ontologies, both perspectives also convey important insights. The challenge for a globally engaged metaphysics of race is to develop a framework that can integrate insights about transnational convergences and divergences. This section proposes a methodological reorientation in debates about racial ontologies that leads to a relational perspective and contrasts with simple contextualist and unificationist models. The following section discusses three case studies that show how this framework can generate novel insights in transnational perspective.

The basic methodological suggestion of this section is to reorient global debates about racial ontologies from a narrow focus on race concepts to a wider focus on race conceptions. The distinction between concepts and conceptions has been prominently used in Rawls' (1971) discussion of a widely shared concept of justice (roughly: equal rights and duties) and his preferred conception (justice as fairness). More recently, Hardimon has employed this distinction to propose a metaphysics of race that focuses on "the logical core" of "the ordinary race concept stripped down to the barest bones" $(2017,28)$. By approaching metaphysical questions about the nature and reality of race in terms of such a narrowly understood concept of race, Hardimon can defend an ontology of race in terms of his three "minimal conditions" (see Sect. 3.2) without having to deny that a richer conception of race involves many other aspects from social hierarchies to false essentialist assumptions.

This restriction to a narrowly conceived core of the concept of race is not unique to Hardimon's proposal but widely shared in current metaphysics of race. For example, anti-realists typically do not deny that there are real biological and social differences associated with race but insist that false (e.g. essentialist and/or racialist) assumptions are at the non-negotiable core of the concept of race (Glasgow 2010). Furthermore, social constructionists do not deny that race is associated with biological differences or false assumptions but insist that race "in the core sense, is 
defined in terms of social relations" (Haslanger 2012, 185). It is therefore not surprising that much of the metaphysics of race has focused on the priority of (e.g. biological, cultural, social, racialist) features at the core of race.

A debate about racial ontologies in terms of a conceptual core "stripped down to the barest bones" comes with the virtue of simplicity as competing accounts characterize the nature of race in terms of one core property (e.g. being posited in a system of white supremacy) or a small set of core properties (e.g. Hardimon's three minimal conditions). In the context of an analysis of global ontologies of race, however, this virtue can turn into a vice by fostering misrepresentations of complex relations: if one keeps the logical core stable across global contexts, one runs the risk of obscuring transnational heterogeneity of racial ontologies. If one claims that different contexts involve different cores, one runs the risk of obscuring transnational continuities of racial ontologies.

Focusing on conceptions rather than concepts increases the complexity of analysis along three dimensions of (1) heterogenous conceptual connections, (2) material property relations, and (3) mappings between them. To illustrate these dimensions, consider two biological properties B1 and B2 such as South Asian ancestry and the sickle cell allele, two cultural properties $\mathrm{C} 1$ and $\mathrm{C} 2$ such as being Muslim or having a preference for Jazz music, two social properties S1 and S2 such as access to higher education and employment opportunities, and two properties D1 and D2 with debunked racialist associations such as innate tendency towards criminality and cognitive profiles. Focusing on conceptions rather than concepts of race allows an analysis of how these properties are conceptually and materially related across national contexts. Figure 1 provides two hypothetical contexts by representing the strengths of conceptual connections through the strength of connecting lines.

Starting with the conceptual dimension, an analysis of Fig. 1 in terms of logical cores would suggest that contexts A and B employ very different race concepts: connections with social properties such as S1 and S2 are dominant in context A while debunked racialist associations with D1 and D2 are dominant in context B. In contrast with such a limited conclusion that only recognizes different cores, a shift
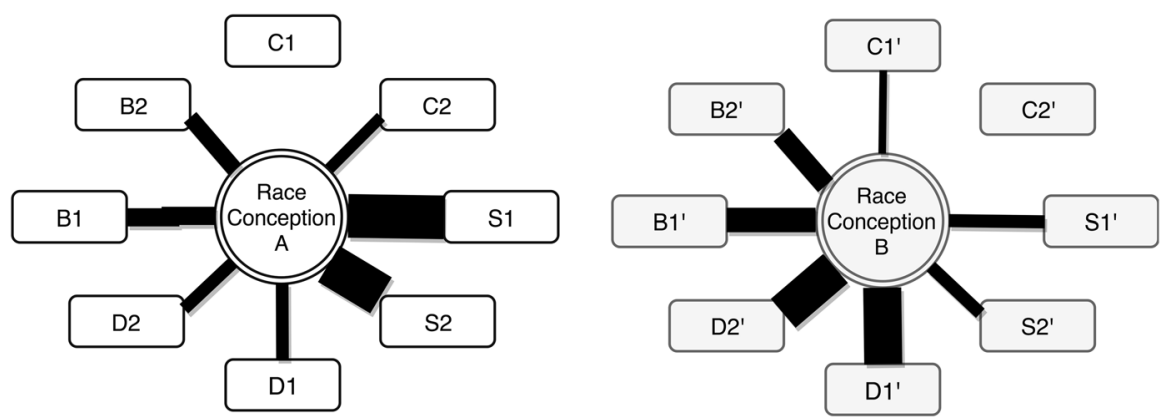

Fig. 1 Representation of two conceptions of race in two distinct contexts. Some associations (B1 and B2) remain relatively stable across contexts while others (C1 and $\mathrm{C} 2$ ) are unique to a specific context. Furthermore, the strength of associations (e.g. S1 and D1) can vary 
towards conceptions allows a fine-grained analysis of conceptual connections. On the basis of such an analysis, it becomes possible to identify subtle similarities and differences along the following lines:

1. Strong discontinuities Some conceptual connections may be significant in one context but (nearly) non-existent in another context. In Fig. 1, being Muslim (C1) is associated with race in context B but not in context A. For example, being Muslim is at least moderately associated with race in most European and North American contexts. In many Middle Eastern countries, however, being Muslim cross-cuts major racial categories. In Saudi Arabia, for example, Muslim immigrants from countries such as Bangladesh, Indonesia, Pakistan, Philippines, Sudan and Somalia have become part of a racially diverse society but the majority in each large racialized group (e.g. Arab, Black African, South Asian, and South East Asian) is Muslim.

2. Partial (dis)continuities Conceptual connections may persist across contexts but vary significantly in strength. In the hypothetical scenario of Fig. 1, social and debunked racialist properties are associated with race in both contexts but social properties S1 and S2 are dominant in context A while debunked racialist assumptions $\mathrm{D}^{\prime}$ and $\mathrm{D} 2^{\prime}$ are dominant in context $\mathrm{B}$. This scenario of partial (dis)continuities is common in racialized contexts that are shaped by the same transnational racialization processes but also adapted to distinct national contexts. For example, the social positioning of the black diaspora across the Americas involves many continuities through shared histories of colonialism and white supremacy but also discontinuities through national adaptations in countries as different as Canada and Suriname.

3. Strong continuities There will be also cases where conceptual connections remain (largely) stable across contexts. In the hypothetical scenario of Fig. 1, the association of race with biological properties B1 and B2 is largely comparable across contexts A and B. (Largely) identical associations can be the product of different processes. First, two contexts may share many associations due to general discourse proximity. For example, Austria and Germany resemble each other in associations of race with Nazi ideology but also share substantial parts of their racial discourses to due cultural, geographic, and linguistic proximity. Second, strong continuities can also be the product of structurally similar responses. For example, consider that not only Austrian and German but also Israeli public discourse tends to prefer eliminativist interpretations of race (Gissis 2008) due to structurally similar reflections on role of racial ideology in the Holocaust. Furthermore, consider appeals to black culture in black nationalism in the United States and in black consciousness in South Africa. In both cases, culturalist interpretations of race can be seen as structurally similar responses to cultural devaluation in dominant systems of white supremacy from Jim Crow to apartheid.

Choosing conceptions rather than concepts as a starting point therefore provides opportunities for fine-grained analyses of the strength of conceptual relations and 
their comparison across national contexts. ${ }^{5}$ In contrast, an analysis of narrow concepts always runs the risk of obscuring either similarities (by proposing different conceptual cores) or differences (by proposing the same conceptual cores) across contexts.

In addition to such an analysis of heterogeneous conceptual connections, a shift towards conceptions also broadens the scope of relevant material property relations: For each of the properties from Fig. 1, one cannot only ask about conceptual but also material connections. Figure 2 illustrates this material aspect with the property of South Asian ancestry (B1). At least for present purposes, it will be sufficient to think of material property relations in terms of relative probabilities in a given context. Relative to context A, for example, having South Asian ancestry substantially increases the probability of being Muslim (C1), while moderately increasing the probability of having a sickle cell allele (B2), and not affecting the probability of innate cognitive profiles (D2).

Just as one can compare conceptual connections across national contexts, transnational comparisons are also possible between material property relations. Figure 3 further expands the example of B1 across two contexts and uses arrows and crosses to indicate an increase and decrease of relative probability. Contexts A and B therefore involve strong contrasts: Having South Asian ancestry (B1) increases the probability of being Muslim (C1) and having access higher education (S1) in context A while decreasing probabilities for $\mathrm{C} 1$ and $\mathrm{S} 1$ in context B.

Such contrasts are common in global comparison. For example, consider South Asian communities in Canada and Saudi Arabia. In Canada, B1 is positively related to $\mathrm{C} 1$ and $\mathrm{S} 1$ as a majority of Canadian Muslims have South Asian ancestry and tend to be better educated than other Canadian populations. In contrast, people with South Asian ancestry constitute the largest non-Muslim population in Saudi Arabia and are largely recent immigrants with limited access to higher education. While such cases of strong variability are common in global contexts, one will also commonly find transnational similarities. For example, B1 will not be (positively or negatively) predictive of innate cognitive profiles in Canada or Saudi Arabia.

Finally, analyses of conceptual connections and material property relations can be mapped onto each other to reveal both matching and mismatching patterns. In many cases, the continued impact of racialist ideologies will lead to mismatches such as associations with behavioral and cognitive differences that simply do not exist. In other cases, conceptual connections will match social realities such as racialized income differences. While most race conceptions involve both matches

\footnotetext{
5 A fully developed account would have to say more about the measurement and operationalization of the strength of conceptual connections. This article does not commit to one specification, as many of the details will depend on wider philosophical commitments on issues such as semantic externalism. For an internalist, it may be attractive to measure the strength of connections directly through experimental evidence of psychological associations or even questionnaires with a representative sample of informants for the given context. However, externalists may appeal to experts or more social science-oriented methods such as discourse analysis in determining how strongly features are associated with race. As the general case for an internationally engaged metaphysics of race should be acceptable for philosophers with different positions on these wider philosophical issues, I will not commit to one specific operationalization.
} 
Fig. 2 Properties are not only conceptually related to race (solid lines) but also materially related with each other (dotted lines). In this example, the dotted lines represent the material relations of the property B1 (South Asian ancestry). In context A, some relations (e.g. South Asian ancestry to educational access) are strong, some relations (e.g. South Asian ancestry to Muslim) are moderate, and some relations (e.g. South Asian ancestry to cognitive profiles) are nonexistent
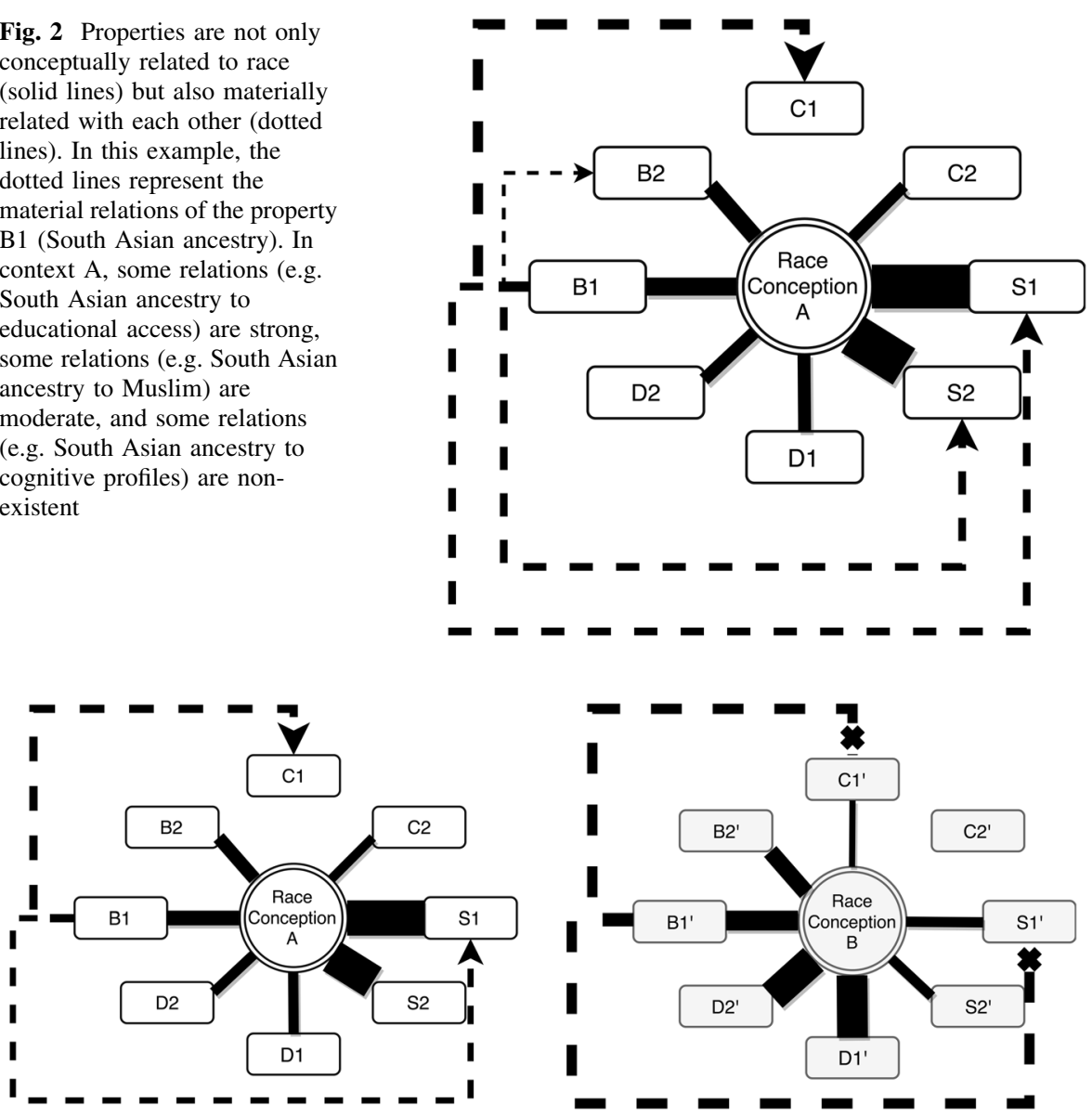

Fig. 3 Arrows indicate positive relations between properties while crosses indicate negative relations. For example, the relation $[\mathrm{B} 1 \rightarrow \mathrm{C} 1]$ is positive in context A but negative in context $\mathrm{B}$

and mismatches, there can be considerable transnational variation in the way how conceptual connections map onto material relations. For example, the arguments from the last section suggest that German conceptions of race strongly emphasize mismatches through essentialist and racialist associations while recent developments of US discourses of race have led to stronger emphasis of socioeconomic realities in conceptions of race (Lipphardt 2018).

To sum up, a shift from concepts to conceptions allows a more fine-grained comparison of transnational continuities and discontinuities of (1) heterogenous conceptual connections, (2) material property relations, and (3) mappings between them. Although such a framework provides opportunities for more fine-grained transnational comparison, it also shifts away from some highly visible issues in current metaphysics of race. Many recent metaphysical debates have focused on whether races exist at all and whether they have a biological or social nature. Approaching these questions through concepts allows the formulation of clear 
metaphysical alternatives such as anti-realism, biological realism, and social constructionism that appeal to competing hypotheses about the core of race concepts.

In contrast, a shift towards conceptions leads to more ambiguous and complex accounts that may not clearly favor one specific account of the nature and reality of race. Race conceptions will typically involve heterogenous associations that partly match (biological, cultural, and social) realities and partly fail to identify real property relations. Race conceptions as represented in Fig. 1 do therefore not provide straightforward answers to questions about the referent of race. In this sense, shifting the focus from concepts to conceptions does not lead to traditional metaphysical positions from anti-realism to biological realism but complements deflationist perspectives as expressed in my earlier critique of the "new metaphysics of race" (Ludwig 2014, 2015) that was based on the assumption that race "is too ambiguous and vague to support a general metaphysical debate about the question whether human races exist" $(2015,258)$.

Of course, the proposed framework does not require such a general deflationism about traditional metaphysical projects as one could also combine the proposed account of conceptions with debates about the concept of race and its referent. While such a combination avoids some of the problems of an exclusive focus on race concepts, there are also reasons to circumvent the issue of conceptual cores in a globally oriented metaphysics of race. As the case studies of the next section will argue in further detail, attempts to isolate a conceptual core can mislead transnational comparisons by either overemphasizing similarities (by postulating the same core) or differences (by postulating different cores) between racial ontologies. At least for the purposes of a globally engaged metaphysics of race, it therefore often seems more adequate to move away from race concepts and to focus on conceptions that provide more complex but admittedly also more ambiguous answers to questions about the nature and reality of race. ${ }^{6}$

Indeed, one may ask whether a framework that circumvents clear answers about the reality and nature of race should still be called "metaphysics" as it seems to be closer to deflationist criticism of the current state of metaphysics (Gannett 2010; Lemeire 2017; Ludwig 2015; Mallon 2006; McPherson 2015). An answer to this question largely depends on how broad "metaphysics" is conceived and whether straightforward answers to questions about the existence and nature of races are seen as a prerequisite of proper metaphysics of race (Hochman 2016). Although these questions about the boundaries of "metaphysics of race" are interesting in their own right, they are not essential for the goal of developing a framework of transnational comparison. Given this goal, the designation of the proposed framework as "metaphysical" is not crucial as long as it provides resources for a

\footnotetext{
${ }^{6}$ Note that this still leaves room for a more normative debate about the core of race concepts in the sense of current accounts of amelioration (Haslanger 2012) and conceptual engineering (Cappelen 2018). Even if race involves many heterogenous conceptual connections that undermine identification of one clear core, it can still be important to discuss which of these dimensions should be emphasized in public and/or scientific discourse.
} 
fine-grained analysis of race conceptions and their mapping onto material property relations.

\section{The relational framework in practice}

The last section introduced a relational perspective on racial ontologies that builds on an analysis of conceptions rather than concepts. This section specifies the framework and its advantages in the context of three applied challenges of a globally engaged metaphysics of race: Sect. 5.1 Addressing partial continuities in transnational perspective, Sect. 5.2 understanding the entanglement of ethnicity and race, Sect. 5.3 addressing global boundary disputes about race. For each of these challenges, it is argued that a narrow focus on concepts leads to overly simple answers while a discussion of conceptions allows to adequately relate racial ontologies.

\subsection{African-American and Afro-German: partial transnational continuities}

Section 3 discussed diverging concepts of race in Germany and the United States as a challenge for unificationist approaches. Given diverging conceptual change in response to the Holocaust and the Civil Rights Movement, it seems plausible that race concepts in Germany and the United States do currently not share the same "logical core" (Lipphardt 2018). However, the claim that race concepts have different cores in different contexts (maybe: false racialist assumptions in Germany, real social properties in the United States) generates different problems as it suggests that races are entirely different entities (e.g. debunked illusions vs. social kinds) in these contexts. The challenge for a comparatively adequate metaphysics of race is therefore to account for partial continuities between contexts such as Germany and the United States.

Audre Lorde's reflections on the category "Afro-German" during her time in Berlin in the 1980s provide a forceful illustration of these partial continuities and their importance in practice. Lorde acknowledges important differences between Germany and the United States and that black Germans constitute a heterogeneous group (e.g. children of Allied army members, immigrants from West Africa to West Germany, and from socialist "brother states" like Mozambique to East Germany). At the same time, Lorde's case for a new category "Afro-German" and the emergence of the Neue Schwarze Bewegung ("New Black Movement") more generally (Oguntoye 1986) was inspired by the Civil Rights Movement and structural similarities with African-American experiences. As Lorde summarizes this complexity in an intersectional context: "as an African American woman [...] I must go to the Afro-German woman and say, 'In what way does your experience differ from mine?' One of the differences that is most obvious that I see is that there are so many more of us in the United States of America, that as African American women we have had a history of recognition of each other, from slavery on, and therefore we have a pool to draw from. I think the Afro-German women have 
existed in a terrible isolation from each other [...]. We need to see, and we do, that our oppressor is the same with very different faces" (2004, 169-170).

A comparative metaphysics of race in Germany and the United States that is based on a narrow focus on race concepts will neglect either the similarities or differences depending on whether the "logical core" is assumed to be stable between Germany and the United States. In contrast, a shift towards conceptions provides metaphysicians of race with tools for analyzing complex real life cases of partial continuities in transnational perspective. Indeed, German and American discourses have developed in diverging directions through post-Holocaust emphasis of Nazi ideologies and post-Civil Rights Era emphasis of continued social stratification. While such divergences may have put different aspects at the core of race concepts, racialization processes remain (conceptually and materially) connected from the use of phenotypic markers to social stratification along racial lines. Addressing this situation through a relational framework in the sense of Figs. 1 and 3 puts philosophers in the position to contribute to a better understanding of these complex situations that involve substantive discontinuities (e.g. resources for black identities) and continuities (e.g. shared experience of oppression).

\subsection{Indígena and mestizo: the entanglement of ethnicity and race}

The social positioning of Indigenous peoples across the Americas constitutes an important challenge for transnational comparisons of racial ontologies. In the United States, Indigenous peoples are commonly (e.g. in the United States Census) identified as a racial group that shares positioning as Native American while also belonging to otherwise different nations, tribes, and communities. Furthermore, one may be inclined to think that such a racialization of Indigenous peoples applies rather uniformly across the Americas given shared histories of European settler colonialism from Tierra del Fuego to Newfoundland.

However, Latin American scholarship on the category indígena indicates important divergences that cast doubt on simple unificationist strategies. One crucial difference is the emphasis of mestizo as a mediating category in Latin American countries such as Colombia (Leal 2010), Ecuador (Clark 2007), Mexico (Ruiz 2001) and Peru (de la Cadena 2007a) that strongly differs from mixed-race in the United States. Not only does mestizo often constitute the largest population group but mestizaje (as the process of "race mixture") has been historically a core element of Latin American nation building as famously illustrated by Vasconcelos' (1925) Raza Cósmica ("Cosmic Race") but also already articulated by nineteenthcentury authors like Samper 1861 who claimed that "the New World is destined to be to be the theater of the fusion and reconciliation of the races, thus inaugurating the foundations of a new civilization. But what civilization? A mestizo civilization [that is] destined to regenerate the world, through [...] fraternity" $(1861,79$, translation by author).

Nation building through an ideology of mestizaje has ontological consequences by making indígena and mestizo at least partly about cultural and social assimilation. For the Ecuadorian context, for example, Clark argues that "mestizaje was conceived primarily as a social rather than biological process" (2007, 151, 
translation by author) that aimed for the transformation of allegedly uncultured indios into cultured mestizos. Wade makes a similar point for the Peruvian context when arguing that an "indigenous migrant from the highlands of Peru who becomes a domestic maid in Lima is on her way to becoming a mestizo woman" $(2017,39)$. For the Mexican context, Loza $(2016,33)$ observes that "mestizaje was presented as the solution to integrating indígenas, and there were a myriad of avenues to transform indígenas to mestizo." Finally, de la Cadena emphasizes that these aspects of socio-cultural fluidity are not only reflected in the imperative of assimilation but also in Indigenous resistance: "Indigenous rejection of mestizaje is not rejection of mixing. It is rejection of the epistemologies of modernity that declare their opposition to tradition and deny [...] ways of being "non-modern" " (2007b, 30, translation by author).

Even if these socio-cultural aspects are of crucial importance in Latin American contexts, it would be a mistake to conceive the distinction between indigena and mestizo as purely cultural and free of biologization (Castañeda 2016). For example, Delgado's detailed case study of forensic anthropology in Mexico does not only show how indigena became associated with distinct facial features but also "part of the biological representation of crime in Mexico and Latin America" (2014, 126, translation by author). Wade et al.'s Mestizo Genomics provides another case study of the persistence of biologization with ambiguous relations to racialization: "Our research indicates that, despite the fact that most geneticists in Latin America actively deny the validity of race as a biological category, genetic science might produce knowledge and interpretations that, while they appear nonracial to genetic experts, might look a lot like race to the nonexpert in genetics" $(2014,2)$.

How do these elements of cultural fluidity, social subordination, and biologization affect the status of indigena as a racial category? Does cultural fluidity show that indigena in Latin America is an ethnic category while Native American in the United States is a racial category? Or do continued social subordination and forms of biologization expose indígena as a covert racial category? Competing philosophical accounts of race concepts seem to imply dramatically different answers in such cases of "partially racialized groups" (Blum 2002, 32). For example, socio-cultural transitions from indigena to mestizo undermine Hardimon's minimal requirements of distinct visual features and geographic ancestry. Insofar as these requirements constitute the conceptual core of race, indigena seems to be an ethnic but not a racial category. And indeed this is a familiar framing in many Latin American contexts. As Leal points out: "In Colombia, for example, the concept of 'ethnicity' came to life to designate Indigenous groups but not the rest of the population. [...] The majority of Colombians do not have any place in ethnic classification" (2010, 422, translation by author). In contrast, many social constructionist accounts of race (e.g. Haslanger 2012) will interpret indígena as a paradigmatic racial category given the subjugation of Indigenous peoples on the basis of biological markers and assumed ancestry.

The problem with such answers (no matter whether they affirm or reject the status of indigena as a racial category) is that they provide overly simple accounts of highly complex constellations. Indígenas in Latin America are positioned through a heterogenous and often inconsistent blend of biological, cultural, and social 
elements that incorporate both ethnic and racial dimensions. A metaphysics of race that prioritizes one of these dimensions and simply affirms/denies the status of indígena as a racial category will be of little help in understanding racialization in Latin America and may actually distort the much more nuanced insights of Latin American scholarship. Moving from concepts to conceptions provides resources for analyzing this complexity without simply declaring indigena either ethnic or racial. Indeed, such an analysis will allow to acknowledge racial continuities between Latin America and the United States such as the position of Indigenous peoples in nation states that are the product of European settler colonialism. At the same time, it can also acknowledge elements such as cultural fluidity that distinguish indigena from racial categories in the United States.

\subsection{Tibetan and Uighur: addressing boundary disputes}

The status of minority groups in China as racial groups has become a focal point of controversies about global boundaries of race (Dikötter 2015; Law 2012; Wang et al. 2003). Indeed, it is uncontroversial that prejudice and discrimination have been common in China both in historical relations to border communities and current attitudes towards minorities such as Tibetans and Uighurs. What is controversial, however, is whether these groups should be conceptualized as racial (rather than "merely" ethnic) and as victims of racism (rather than "merely" ethnic discrimination).

If metaphysics of race is approached through narrow core concepts, even slight variation at the core will lead to drastically different demarcations in these kinds of boundary disputes. Maybe the most telling examples are the radically different implications of different variants of social constructionism. Consider Haslanger's influential account of race in terms of "observed or imagined bodily features presumed to be evidence of ancestral links to a certain geographical region" (2012, 236). Such a definition applies rather straightforwardly to Tibetans and Uighurs in China and therefore seems to identify them as racial groups. More generally, Haslanger's account suggests a highly inclusive strategy in boundary disputes that affirms the existence of races in countless contexts that are historically and geographically independent of European modernity (Hochman 2017). In contrast, recall earlier discussions of race in terms of a sociopolitical system of white supremacy. Given such an account, Tibetans and Uighurs are not racial groups because their discrimination is not grounded in this particular sociopolitical system. More generally, this variant of social constructionism seems to imply a highly exclusive strategy in global boundary disputes about forms of discrimination and violence that are not specifically grounded in European colonial orders.

While it is possible to defend highly inclusive or exclusive accounts in boundary disputes, there is a risk of metaphysicians providing simplistic answers that fall behind the state of "interactionist" models (Dikötter 2015; Bonnett 2018) in the empirical literature that aim to understand the emergence of racial orders through the entanglement of elements with different historical and geographical origins. Embracing a relational framework puts philosophers in a position to contribute to substantial analyses of nuanced connections rather than postulating overly simple 
demarcation criteria that decide at what point a group "really" counts as a racial group.

\section{Conclusion}

The aims of this article have been both critical and constructive. On the one hand, I argued that simple contextualist and unificationist models are insufficient for understanding race on a global scale. On the other hand, I outlined a positive proposal for globally engaged metaphysics of race that shifts attention from concepts to conceptions. I have argued that this shift leads to a relational perspective on racial ontologies in terms of transnationally related but nonetheless distinct conceptions and their mappings onto property relations. Finally, I have sketched some benefits of this relational perspective for engaging with Sect. 5.1 partial continuities of racialization practices, Sect. 5.2 entanglements of ethnicity and race, and Sect. 5.3 global boundary disputes about race. These benefits also illustrate a larger opportunity for integrating relational accounts of the nature and reality of race with empirical research in ethnic and racial studies. It does not only allow philosophers to engage more adequately with complex empirical evidence but also provides social scientists with novel resources for analyzing and organizing this complexity.

Acknowledgements A previous version of this article was presented at the European Philosophy of Science Association (EPSA). I would like to thank the EPSA audience and my symposium co-organizers Magali Bessone, Sophia Efstathiou, Ludovica Lorusso, and Maria Kronfeldner for helpful comments.

Funding Funding was provided by Nederlandse Organisatie voor Wetenschappelijk Onderzoek (Grant No. 275-69-006).

Open Access This article is distributed under the terms of the Creative Commons Attribution 4.0 International License (http://creativecommons.org/licenses/by/4.0/), which permits unrestricted use, distribution, and reproduction in any medium, provided you give appropriate credit to the original author(s) and the source, provide a link to the Creative Commons license, and indicate if changes were made.

\section{References}

Amjahid, M. (2017). Unter Weißen. München: Hanser.

Arndt, S. (2009). Rassen gibt es nicht, wohl aber die symbolische Ordnung von Rasse. In S. Arndt, M. Maisha Eggers, G. Kilomba \& P. Piesche (Eds.), Mythen, Masken Und Subjekte (Vol. 2, pp. 340-362). Münster: Unrast.

Atkin, A. (2017). Critical philosophy of race: Beyond the USA. Journal of Applied Philosophy, 34(4), 514-518.

Balibar, E. (1992). Le mot race n'est pas « de trop » dans la constitution française. Mots, 33(1), 241-256. Barskanmaz, C. (2011). Rasse-Unwort des Antidiskriminierungsrechts? Kritische Justiz, 44(4), 382-389. Berg, M., \& Wendt, S. (2011). Racism in the modern world. New York: Berghahn.

Bessone, M. (2013). Sans distinction de race?. Paris: Vrin. 
Blum, L. (2002). I'm not a racist, but.... Cornell: Cornell University Press.

Bonnett, A. (2018). Multiple racializations in a multiply modern world. Ethnic and Racial Studies, 41(7), 1199-1216.

Cappelen, H. (2018). Fixing language. Oxford: Oxford University Press.

Castañeda, C. (2016). Antropología étnica. Anuario Colombiano de historia social y de la cultura, 43, 243-275.

Cheng, Y. (2011). From campus racism to cyber racism. The China Quarterly, 207, 561-579.

Chor, D., \& Lima, A. (2005). Aspectos epidemiológicos das desigualdades raciais em saúde no Brasil. Cad Saúde Pública, 21(5), 1586-1594.

Clark, K. (2007). Raza, 'cultura' y mestizaje en el primer censo de Ecuador. In M. de la Cadena (Ed.), Formaciones de Indianidad (pp. 149-171). Bogotá: Envión.

Cremer, H. (2010). Ein Grundgesetz ohne 'Rasse' policy paper. Berlin: Deutsches Institut für Menschenrechte.

Cruse, H. (2009). Rebellion or revolution? Minneapolis: University of Minnesota Press.

De la Cadena, M. (2007a). Introducción. In M. de la Cadena (Ed.), Formaciones de Indianidad (pp. 7-34). Bogotá: Envión.

De la Cadena, M. (2007b). ¿Son los mestizos híbridos? In M. de la Cadena (Ed.), Formaciones de Indianidad (pp. 83-116). Bogotá: Envión.

Delgado, A. (2014). El Dominio Del Rostro. (Dissertation, Universidad Nacional Autónoma de México, 2014).

Deutscher Bundestag (1949). Grundgesetz der Bundesrepublik Deutschland. https://www.bundestag.de/ gg. Accessed 4 Aug 2018.

Dikötter, F. (2015). The discourse of race in modern China. Oxford: Oxford University Press.

Doron, C. (2016). L’homme altéré: Races et dégénérescence. Paris: Champ Vallon.

Du Bois, W. E. B. (1903/2007). The souls of black folk. Oxford: Oxford University Press.

Du Bois, W. E. B. (1971). Speeches and addresses, 1920-1963. New York: Pathfinder.

Federl, F. (2014). Afrikaner in China: Chinas neues Rassismus-Problem. Die Zeit. http://www.zeit.de/ politik/ausland/2014-04/rassismus-china-guangzhou. Accessed 4 Aug 2018.

Gannett, L. (2010). Questions asked and unasked. Synthese, 177(3), 363-385.

Geulen, C. (2004). Wahlverwandte: Rassendiskurs und Nationalismus im Späten 19 Jahrhundert. Hamburg: Institut für Sozialforschung.

Gissis, S. (2008). When is 'race' a race? 1946-2003. Studies in History and Philosophy of Biological and Biomedical Sciences, 39(4), 437-450.

Glasgow, J. (2010). A theory of race. New York: Routledge.

Glasgow, J. (2011). Another look at the reality of race, by which i mean race. In A. Hazlett (Ed.), New waves in metaphysics (pp. 54-71). London: Palgrave Macmillan.

Gramsci, A. (2014). Quaderni del carcere. Torino: Einaudi.

Hardimon, Michael O. (2014). The concept of socialrace. Philosophy and Social Criticism, 40(1), 69-90.

Hardimon, M. (2017). Rethinking race. Cambridge: Harvard University Press.

Haslanger, S. (2012). Resisting reality. Oxford: Oxford University Press.

Heng, G. (2011). The invention of race in the European middle ages. Literature Compass, 8(5), 315-331.

Hochman, Adam. (2016). In defense of the metaphysics of race. Philosophical Studies, 174(11), 2709-2729.

Hochman, A. (2017). Replacing race: Interactive constructionism about racialized groups. Ergo. https:// doi.org/10.3998/ergo.12405314.0004.003.

Hund, W. (2017). Wie die Deutschen weiß wurden. Stuttgart: Metzler.

Law, I. (2012). Red racisms. Basingstoke: Palgrave Macmillan.

Leal, C. (2010). Usos del concepto raza en Colombia. In C. Mosquera (Ed.), Debates sobre ciudadanía y políticas raciales en las américas negras (pp. 393-440). Bogotá: Universidad Nacional de Colombia.

Lemeire, O. (2017). Beyond the realism debate. Studies in History and Philosophy of Biological and Biomedical Sciences, 59(2016), 47-56.

Lipphardt, V. et al. (2018). Lost in Translation. Süddeutsche Zeitung. April 18, 2018.

Lorde, A. (2004). Conversations with Audre Lorde. Jackson: University Press of Mississippi.

Loza, M. (2016). Defiant Braceros. Chapel Hill: UNC Press.

Ludwig, D. (2014). Hysteria, race, and phlogiston. A model of ontological elimination in the human sciences. Studies in History and Philosophy of Biological and Biomedical Sciences, 45, 68-77.

Ludwig, D. (2015). Against the new metaphysics of race. Philosophy of Science, 82(2), 244-265. 
Mallon, R. (2006). Race: Normative, not metaphysical or semantic. Ethics, 116(3), 525-551.

McPherson, L. (2015). Deflating 'race'. Journal of the American Philosophical Association, 1(4), $674-693$.

Mills, C. (2003). From class to race. Lanham: Rowman \& Littlefield Publishers.

Muniz, J., \& Bastos, J. (2017). Volatilidade classificatória e a (in)consistência da desigualdade racial. Cadernos de Saúde Pública, 33, e0082816.

Oguntoye, K. (1986). Farbe Bekennen: Afro-Deutsche Frauen auf den Spuren ihrer Geschichte. Berlin: Orlanda Frauenverlag.

Oliven, A. (2007). Ações afirmativas, relações raciais e política de cotas nas universidades. Educação, 30(1), 93-107.

Plümecke, T. (2014). Rasse in der Ära der Genetik. Göttingen: Transcript.

Rawls, J. (1971). A theory of justice. Cambridge: Harvard University Press.

Reich, D. (2018). How genetics is changing our understanding of 'race'. New York City: The New York Times.

Root, M. (2000). How we divide the world. Philosophy of Science, 62, 628-639.

Ruiz, A. (2001). La india bonita: nación, raza y género en el México revolucionario. Debate Feminista, 24, 142-162.

Samper, J. (1861). Ensayo sobre las revoluciones políticas y la condicion social de las repúblicas colombianas. Paris: Thunot.

Schaap, J. (2014). Gebonden aan witheid. Sociologie, 10(1), 78-83.

Simon, P. (2008). Les statistiques, les sciences sociales françaises et les rapports sociaux ethniques et de « race ». Revue française de sociologie, 49(1), 153-162.

Spencer, Q. (2014a). The unnatural racial naturalism. Studies in History and Philosophy of Biological and Biomedical Sciences, 46, 38-43.

Spencer, Q. (2014b). A radical solution to the race problem. Philosophy of Science, 81(5), 1025-1038.

Vasconcelos, J. (1925). La raza cósmica: misión de la raza iberoamericana. México: Trillas.

Wade, P. (2017). Race and ethnicity in latin America. London: Pluto Press.

Wade, P., et al. (2014). Mestizo genomics. Durham: Duke University Press.

Wang, Q., et al. (2003). On the concept of race in chinese biological anthropology. Current Anthropology, 44(3), 403.

Wekker, G. (2016). White innocence. Durham: Duke University Press.

Winant, H. (2001). The world is a Ghetto. New York: Basic Books.

Winant, H. (2004). The new politics of race. Minneapolis: University of Minnesota Press. 